\title{
THE WEMINDJI KIMBERLITES: EXPLORATION AND GEOLOGY
}

\author{
Jacques Letendre ${ }^{1}$, Marc L'Heureux ${ }^{1}$, Tom Nowicki ${ }^{2}$ and Robert Creaser $^{3}$ \\ ${ }^{1}$ Majescor Resources Inc, Canada; ${ }^{2}$ Mineral Services Canada Inc, Canada $;{ }^{3}$ Geospec Consultants Ltd., Canada
}

\section{INTRODUCTION}

Kimberlite was discovered on the east shore of James Bay in early 2002; it represents the first known occurrence of kimberlite in the Quebec lowlands (Fig. 1). The Wemindji Project is located 30 to 60 kilometers east of the Cree village of Wemindji, along the eastern coast of James Bay. The property is easily accessible year-round via an all-weather road which crosses the property from east to west, linking Wemindji to the paved Matagami-Radisson highway. Climate in the region is continental; temperatures vary between $-40^{\circ}$ in winter and $30^{\circ}$ in summer. The ice on the lakes and rivers usually breaks up during the last week in May. Summers are generally quite hot with long days. Freeze-up starts in November.

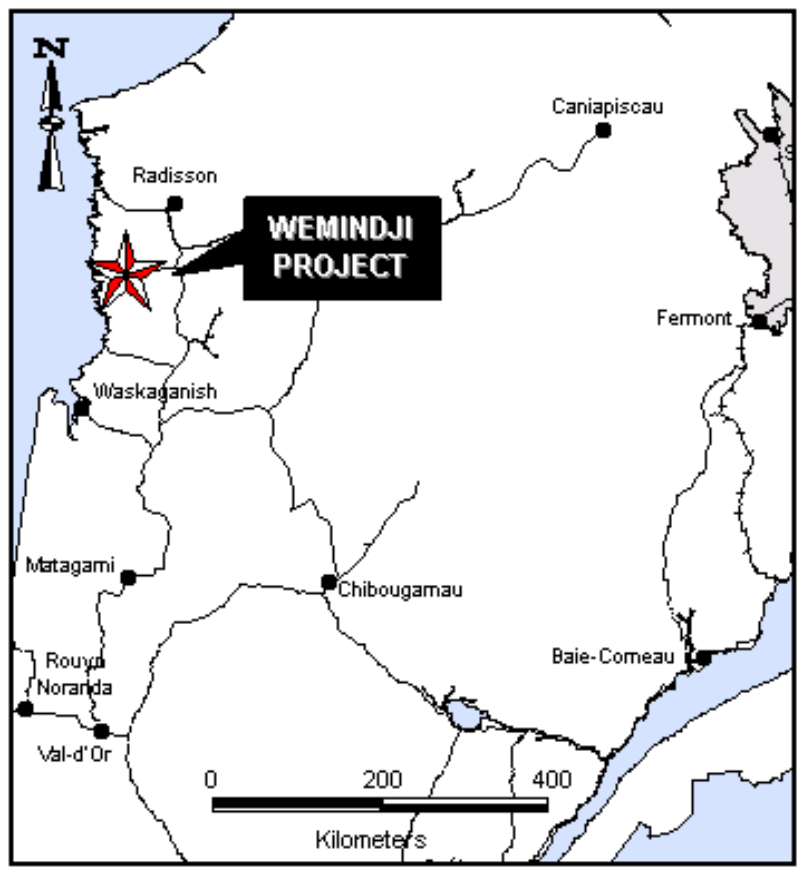

Figure 1: Location of the Wemindji project.

\section{GEOLOGY}

\section{BEDROCK}

The region is underlain by rocks of the Superior Province, an early cratonic terrain composed of a succession of Archean plutonic, metasedimentary and volcanic belts (Moorhead et al. 1999 and Hocq, 1994). The Wemindji area is located within the La Grande Subprovince. This Pre-Kenoran (2.74 Ga) supracrustal sequences rests on older gneissic country rocks which have been grouped under the Langelier Complex. Although these ancient gneisses have been dated at 2.8 $\mathrm{Ga}$, there is some strong evidence of a remobilized basement dating back to more than $3.0 \mathrm{Ga}$ (Goutier et al. 1999). These terrains represent a complex assemblage of alternating metamorphic troughs and peaks, the volcanic belts representing the greenschistfacies minima and the plutonic terrains, the granulitefacies maxima. The depth of peneplanation progressively increases from west to east in the subprovince, the volcano-sedimentary belts (representing lower metamorphic facies) being more abundant and better preserved in the western half compared to the east where they occur as relics.

In the region, the cover rocks are limited to a series of small Early Proterozoic $(>2.2 \mathrm{Ga})$ epicratonic sedimentary basins assigned to the Sakami Group. The basins lie within an alignment of rift grabens filled with continental sandstones. No tectonogenesis, other than crustal extension, has affected the underlying and surrounding rocks forming the basement.

Alkaline intrusions are fairly rare in Québec's Near North region. It is interesting to note that porphyry alkaline syenites have been identified in the extension of the Sakami graben. The first occurrence outcrops on two islands in James Bay, near Wemindji. The second, mapped as recently as 1999, is located near Bruce Lake. The Wemindji syenite is interpreted as a late intrusion. It is probable that the intrusions are associated with a northeastern extension of the Kapuskasing Structural Zone, rather than the Sakami lineament as the first, which is a significant element of the geology of northern Ontario is characterized by them. Although there no evidence of the Kapuskasing Event in Quebec, the Wemindji project area does lie directly on its prolongation.

A number of major weakness zones, breaks and lineaments, most probably affecting the basement at depth, have been identified in Québec's Near North region. The reader is referred to Moorhead (1999) for more details. Let us simply mention here the presence of a well-defined system of fractures which corresponds 
roughly to the east-west alignment of basins hosting the Sakami Group; this axis also coincides with the La Grande volcanic belt. While the fractures presumably correspond to a zone of crustal extension, the grabens are in-filled with an accumulation of continental sediments, their geometry being controlled by a series of brittle faults. Important faults in the area include the Grande Rivière and Petite Rivière de la Baleine faults. Several major cross-cutting shear zones are also reported.

\section{SURFICIAL}

The landscape is dominated by bedrock cored hills, either bare or overlain by a thin till cover (Lee et al., 1959). A thicker basal till occurs either as featureless or modeled (drumlins and crag-and-tail) deposits and often occupies the major, deeper valleys. Glaciofluvial deposits, eskers, complexes or plains, are rare in the James Bay Region and none were reported for the Wemindji area.

All these deposits were frequently extensively modified by the waters of proglacial Lake Ojibway and postglacial Tyrrell Sea which invaded the territory less than 10,000 years ago (Vincent, 1985). The Tyrrell Sea in particular, not only generated thick deep water (clayey silt and silty clay) and extensive beach/platform (sand, gravel, pebbles and blocks) deposits, but it also partially reworked the pre-existing glacial deposits and left characteristic beach ridge landforms.

Finally, organic deposits, marked by peat bogs and swamps, occasionally cover flat valley floors. Very narrow fluvial sediments are mostly restricted to river channel.

Recent reconstructions of the Labrador Sector of the Laurentide Ice Sheet that covered the area of interest show that the lower Wisconsinan ice flow centre was probably located just north of Lac Mistassini, the centre presumably migrating some $500 \mathrm{~km}$ to the northeast during the upper Wisconsinan (Parent et al., 1995). In fact, the oldest ice flow recorded by the glacial striae is towards the northwest, the most recent being to the west or southwest (Veillette et al., 1999, Charbonneau 2002).

A recent study of the glacial and postglacial evolution of the area describes lithofacies that support the existence of the following widely distributed glacial units: one horizon, if not two, of ablation till resting over basal til; the latter is the most reliable medium for indicator mineral sampling. Both lithofacies are readily discernable from the post glacial sediments consisting of well-sorted littoral gravel and fossiliferous pack-ice diamict. Apart from certain valley floors filled by fine grained marine silt, the area is amenable to the indicator tracing techniques.

\section{EXPLORATION}

The vast territory surrounding Wemindji was the focus of significant exploration work by De Beers Canada Exploration Inc. from 1996 to 1998. The company conducted an extensive program of glacial sediment sampling in the James Bay region. In 1998, following the discovery of indicator minerals in the Wemindji area, De Beers acquired secured exploration rights over nearly $2,000 \mathrm{~km}^{2}$. The holdings were later reduced to $50 \mathrm{~km}^{2}$ in 1999 after more detailed sampling helped better define the head of an indicator mineral dispersion train. This last permit was also abandoned in June 2000 after an exhaustive, but unsuccessful search for the primary source. Their activities included highdensity till sampling, high-resolution geophysical surveying (combined magnetic and electromagnetic detection methodologies) and core drilling. De Beers attributed its failure to find the primary source of the indicator minerals to the noisy magnetic background which makes the detection of anomalies difficult.

Majescor Resources has been active in the Wemindji area since 1998, first through the acquisition of a number of claim blocks covering magnetic targets selected from government regional airborne surveys, then through limited sampling of glacial sediments down-ice of these. On the strength of positive results, the company gradually widened the scope of its sampling campaigns to a more regional level starting from June 1999, defining a broad scatter of kimberlitic indicator minerals to the east of a permit then held by De Beers.

Exploration in the region was hampered by the effects of the Tyrrell Sea which has extensively reworked the glacial deposits at surface, scouring the abundant bedrock knobs clean, leaving a thin veneer of sand and gravel lag or clayey silt and spreading indicator minerals widely. As well, magnetic surveying has proven inefficient as a tool because of the high noise level of the Archean basement.

However, the following sequence of exploration did lead to the discovery of the first kimberlite source rock: regional and subsequent semi-detailed sampling of glacial and post-glacial (marine lag) sediments, and definition of local "hot spots" characterized by elevated indicator counts, fragile reaction textures on garnet and ilmenite or primary morphology of the grains, etc. 
As of late 2001, the activities focused mostly on one hot spot in particular where counts up to 12,000 indicators in basal tall were reported, as well as two of the three known occurrences of kimberlite float. Additional work involved ground geophysics, including magnetism, electromagnetism, resistivity and gravity, and finally mechanical pitting on a loose grid over the area of the hot spot to define a dispersion train of indicator minerals in the till underlying the zone of marine reworking, and if possible, of the ablation till. The later activity succeeded in delineating a two kilometer long dispersion train trending $\mathrm{N} 225^{\circ}$, i.e. along the latest glacial orientation. Core drilling in early 2002 at the head of the train resulted in the discovery of the kimberlite source rock .

\section{KIMBERLITE}

All 15 holes drilled within an area of $400 \times 500 \mathrm{~m}$ have intersected the sub-horizontal kimberlite which averages $2 \mathrm{~m}$ and occurs at depths of between 4 and 32 $\mathrm{m}$ (Fig. 2). The geometry of the intrusion has yet to be determined, but it either occurs as a shallowdipping/folded/faulted sill or as a series of stacked sills. The later is likely as the characteristics of the kimberlite intersections indicate different intrusion styles/macroscopic facies are present. Some sills exhibit multiple intrusive phases, most often finegrained, while others show coarser material with abundant large olivine and other megacrysts up to $3 \mathrm{~cm}$ (Fig. 3).

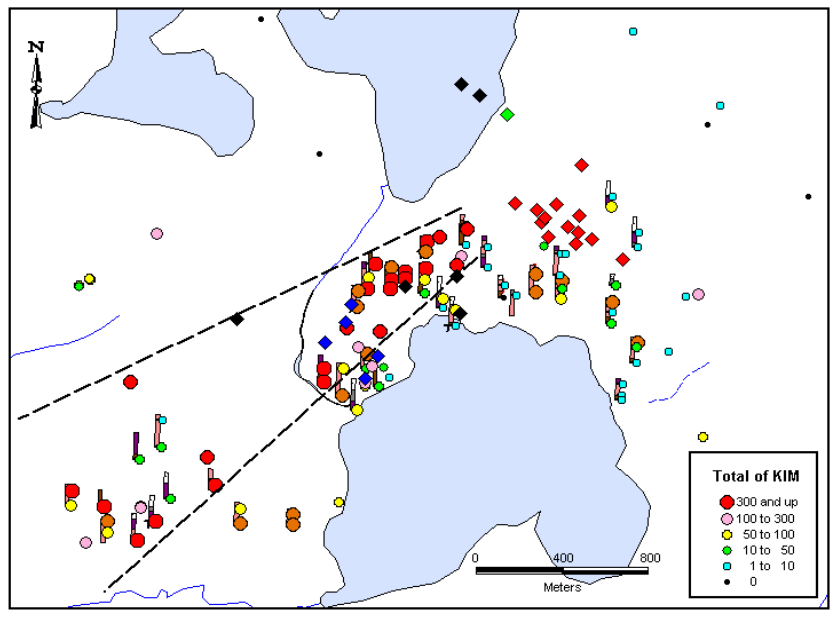

Figure 2: Location of core drill holes. Black lozenge: sterile, red lozenge: kimberlite sill intersection near surface, green lozenge: thin kimberlite dyke intersection at depth

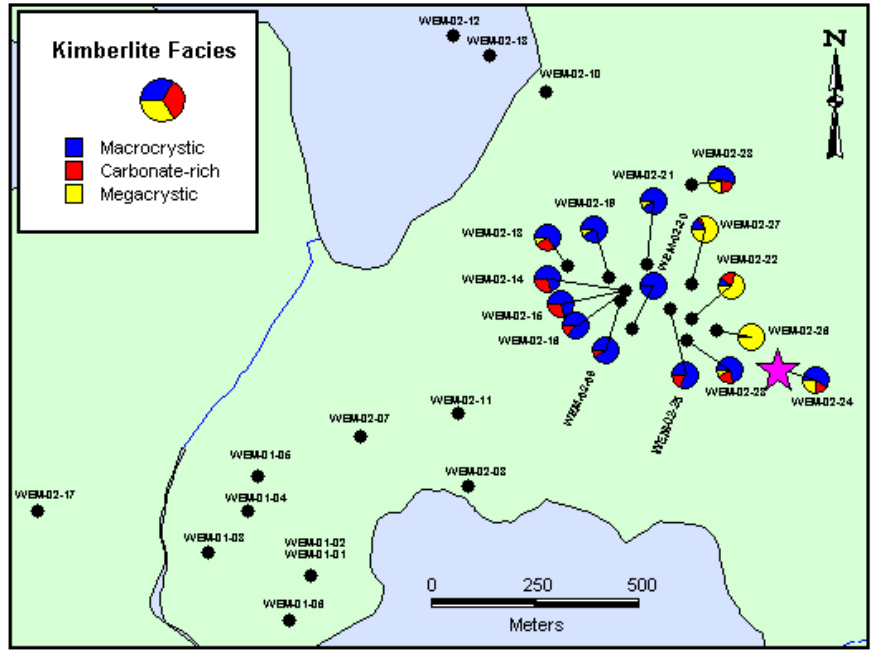

Figure 3: Distribution of macroscopic facies in Wemindji kimberlite sill. Star symbol indicates location of mini-bulk sample.

The petrographic characteristics of the Wemindji kimberlite are unusual and are discussed in a separate contribution. The rock is characterized as a dolomiterich highly-differentiated hypabyssal kimberlite. In terms of kimberlite nomenclature, they range from dolomite spinel kimberlite through macrocrystal dolomite apatite kimberlite to garnet - magnesian ilmenite macrocrystal kimberlite. Also, the extreme modal variation between and within the sills makes correlation of the intrusions impossible between the various drill holes

In order to process sufficient kimberlite so as to ascertain its diamond content, and in view of the paucity of the kimberlite available through the short core drilling intersections and the relative shallowness of the deposit, a pit some $10 \mathrm{~m}$ wide $\mathrm{x} 10 \mathrm{~m}$ long $\mathrm{x} 11$ $\mathrm{m}$ deep was excavated with explosives following the stripping of $3.7 \mathrm{~m}$ of glacial and glacio-marine overburden. The overlying granite was subsequently removed and the kimberlite rock from the 1.8 -meter thick, sub-horizontal sill extracted. An aggregate of 8.4 tonnes of kimberlite was sent to the Saskatchewan Research Council laboratory. The material was separated into two samples, one of selected coarsegrained megacryst-rich kimberlite, which make up to $25 \%$ of the rock at this site, the other of run-of-the-mill kimberlite, which were individually processed for $+0.85 \mathrm{~mm}$ diamonds. In addition, $190 \mathrm{~kg}$ of the kimberlite was submitted for microdiamond extraction by caustic fusion at the same laboratory. Although no diamonds greater than $0.85 \mathrm{~mm}$ were recovered from larger samples of kimberlite, two microdiamonds were 
extracted from caustic fusion of smaller ones. The largest of the two stones was a white cloudy very pitted octahedral diamond, $0.60 \times 0.58 \times 0.46 \mathrm{~mm}$ in dimension, and the second stone was a white frosted fractured etched macle, $0.44 \times 0.34 \times 0.08$ in dimension.

\section{MANTLE XENOCRYST MINERALOGY}

Two kimberlite samples totaling $18.8 \mathrm{~kg}$ were submitted to Mineral Services Canada and South Africa for kimberlitic indicator mineral analysis, including the determination of the abundance and composition of mantle-derived indicator minerals. The results were interpreted in term of diamond potential and the nature and thermal state of the lithosphere sampled by the source kimberlite.

The indicator mineral assemblage is dominated by super abundant ilmenite, with secondary garnet, and uncommon chromite and chrome diopside. This suggests extensive sampling and preservation of lithospheric mantle material, including a significant population of megacrystic minerals. Mineral compositions indicate the presence of minor amounts of diamond-inclusion type garnets (G10 Peridotitic and Group 1 Eclogitic garnets) suggesting that the kimberlite has sampled high-interest, potentially diamondiferous mantle. However, the diamondinclusion parageneses constitute a very low portion of the garnet population and, overall, the indicator mineral results are not consistent with the presence of economic concentrations of diamonds. Results of the $\mathrm{Ni}$ thermometry indicate that most of the garnet equilibrated at relatively high temperatures ranging from ca. 1050 to $1300{ }^{\circ} \mathrm{C}$, consistent with a source within the deep lithospheric mantle.

Mineral compositions indicate that the ilmenites and approximately $50 \%$ of the garnets and clinopyroxenes recovered from samples of the Wemindji sill are of megacrystic origin. The remaining garnets are predominantly lherzolitic, with a subordinate probable wehrlitic population and rare harzburgitic grains also present. Only a very small proportion of the clinopyroxenes recovered are derived from garnet lherzolite (the remainder are of megacrystic and probable wehrlitic origin).

\section{AGE DETERMINATION}

Small sub samples of each kimberlite type, fine grained macrocryst-free aphanitic kimberlite and ilmenite/garnet/orthopyroxene macrocryst-dominated kimberlite were forwarded to Geospec Consultants Limited for radiometric dating.

$\mathrm{Rb} / \mathrm{Sr}$ dating of phlogopite macrocrysts yielded an isochron age of 629 +/- 29 Ma for the macrocrystdominated sample. A $\mathrm{Rb} / \mathrm{Sr}$ model age determined for the macrocryst-free sample indicates no significant age difference for these two rock types (within the precision of the method).

This age is older than that recently obtained for the Beaver Lake kimberlite (568 Ma) located some $500 \mathrm{~km}$ to the east in the Otish Mountains.

\section{REFERENCES}

Goutier, J., Dion, C., Lafrance, I., David, J., Parent, M., Dion, D-J., 1999. Géologie de la région des lacs Langelier et Threefold, SNRC (33F/03 et 33F/04). Ministère des Ressources Naturelles du Québec. RG 98-18 (in French).

Hocq, M., 1994. La province du Supérieur. In : Géologie du Québec, Ministère des Richesses Naturelles du Québec. MM 94-101, pp.7-20 (in French).

Lee, H.A., Eade, K.E., Heywood, W.W., 1959. Surficial geology, Sakami Lake (Fort George-Great Whale area), New Quebec, Geol. Surv. Can., Map 52-1959, scale $1 / 506,880$.

Moorhead, J., Beaumier, M., Lefèvre, D., Bernier, L., Martel, D., 1999. Kimberlites, linéaments et rifts crustaux au Quebec. Géologie Québec. MB 99-35 (in French).

Parent, M., Paradis, S.J., Boisvert, E., 1995. Ice-flow patterns and glacial transport in the eastern Hudson Bay region: implications for the late Quaternary dynamics of the Laurentide Ice Sheet. Can. Jour. of Earth Sciences. 32, 2057-2070.

Veillette, J.J., Dyke, A.S., Roy, M., 1999. Ice-flow evolution of the Labrador Sector of the Laurentide Ice Sheet: a review, with new evidence from northern Quebec. Quaternary Science Reviews. 18, 993-1019.

Vincent, J.S., 1985. Géologie des formations en surface, Chisasibi, Québec.. Geol. Surv. Can. Map 1592A, scale 1/100,000 (in French).

Contact: JPJ Letendre, 2720 Machabee, St Laurent, QC, Canada, H4K 1K1, E-mail: jpjletendre@cs.com 